\title{
THE PTINID BEETLE, TRIGONOGENIUS GLOBULUM, SOLIER, BREEDING IN ARGOL.
}

\author{
By Hugh Scott, M.A., Sc.D., F.E.S., \\ Curator in Entomology, University of Cambridge.
}

In March 1920 my attention was called by Dr. F. W. Dootson, University Lecturer in Chemistry, to the fact that a beetle was breeding in numbers in a jar of argol in the Chemical Laboratory of Cambridge University. The insect proved on examination to be the introduced Ptinid, Trigonogenius globulum, Solier,* a form related to the household insect, Niptus hololeucus, to which it bears at first sight a slight resemblance.

Argol is the crust or deposit which separates out in barrels of new wine. It contains a high percentage of cream of tartar (potassium bitartrate), and most of the pure stock of that chemical is prepared from it. The argol in which the beetles were living was found to contain about 80 per cent. of potassium bitartrate. The argol was a purplish-red powder of close consistency, and it came to the Chemical Laboratory from London in a bag in 1913. It was placed in an earthenware jar, tightly corked with a wide cork bung. The powder did not quite fill the jar, but a very small air-space was left at the top. $\dagger$ I am assured that the jar was not opened from the time the powder was put in till early in 1920, when the argol was found to be full of adults and larvae of the Trigonogenius. The cork, which I have twice examined, has not been bored through or damaged by insects in any way, and it fits so closely that it is almost impossible that the beetles can have got into the jar down the side of the cork; nor have they been noticed anywhere else in the laboratory. Probably, therefore, some of the insects were in the argol when it came to the laboratory and have continued breeding in it all these years. No other kinds of insects were found in the argol. I am indebted to Dr. Dootson for most of the foregoing particulars and for samples of the infested chemical.

That the beetles were nourishing themselves, not exclusively on the 80 per cent. of potassium bitartrate, but at any rate partly on some of the ingredients forming the other 20 per cent. of the argol, seems to be indicated by the following experiment, carried out at Dr. Dootson's suggestion. Some of the insects were placed on the surface of about two inches depth of pure cream of tartar in a wide-mouthed corked bottle, with plenty of air-space between the surface of the chemical and the cork ; 32 adults and 15 larvae were placed in this on 12th March 1920 . Three and a half hours later almost all the larvae had burrowed down into the white powder, but the adults were still on the surface and showing signs of discomfort. Next day all the larvae but one were below the surface, and also about 23 of the adults ; the remaining adults were still on the surface and one was dead. No further observation was made for nearly three weeks, when (on 1st April 1920) about 14 adults and one larva were seen to be on the surface, while the other 18 adults and 14 larvae had all burrowed some way down into the cream of tartar, and several burrows were risible against the glass sides of the bottle. The bottle was not examined again for nearly a year, when (on 15th March 1921) its contents were turned out, and all the insects were

* Described by Solier in C. Gay's " Historra de Chıle," iv, 1849, p. 464. I have retaned Solıer's original spelling of the specufic name, though in some later works globulum is altered to globulus, which is probably more correct. Solier called the species globulum, but at the same time named a variety of it globosus. Why he gave the former name the neuter ending is difficult to say. He may have intended globulum to be a noun, but in several dictionaries of classical and late Latin which I have seen, the only form of the word is a late Latin noun, globulus.

f In some of the argol which was put into a glass-stoppered bottle, filling it up to the stopper and leaving no air-space, all the insects died. 
found to be dead; there were four adults on the surface and 34 adults below, and remains of about cight larvae were found. It will be noticed that the adults were six more in number than those placed in the bottle the year before, proving that some of the larvae had succeeded in reaching the adult state; most of them when put in were fairly big. But the attempt to start a culture breeding in pure cream of tartar failed. It should be mentioned that no moisture was supplied, but neither was it, of course, in the original jar of argol, which was however far larger and contained a very much greater bulk of chemical than the bottle used in this experiment.

In the original jar of argol the insects were still present in large numbers in April 1921. Series of adults and larvae have been preserved, but I have found only one pupa, though samples of the argol have been looked through on several occasions. This single pupa was found at about the end of March 1921. Mr. Michael G. L. Perkins, who placed some of the argol in a vessel and kept the beetles present in it under observation, obtained about 30 pupae in July 1920 . He has also started cultures of the insect in certain food-stuffs such as oatmeal and raisins, and, so far as his observations have gone, he considers that the generations succeed one another more rapidly in these food-stuffs than in the argol, in which substance the insects appear to be reproducing themselves only at the rate of about one generation a year. He hopes to publish the results of his investigations in the future.

The larva pupates in a cocoon formed of a feltwork of fine threads, secreted by itself. The cocoon is not lined, and the feltwork is easily pulled apart with needles into a loose tangle of threads. The feltwork appears whitish when the argol

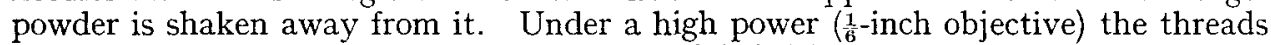
are quite colourless and transparent. Many full-fed larvae, pupae, and adults have been found in these cocoons by Mr. Perkins and myself. Mr. Perkins sifted the argol, to remove all foreign material from it, before he placed his observation culture of the insects in it, thereby proving that the threads are actually produced by the larvae. He thinks that other feltwork is produced in the burrows, besides that actually used in the construction of the cocoons.

Trigonogenius globulum was originally described from Chile, but is very widely distributed. In M. Pic's Catalogue of Ptinidae (1912, Col. Cat., part 41, p. 9), it is recorded from various parts of North and South America, Tasmania, and England. Most of the known species of the genus are, according to the Catalogue, known from Central or South America, and several of them are not known from elsewhere, so that region may be their native home. Fowler \& Donisthorpe (Col. Brit. Isl., vi, 1913 , p. 147) state that it has occurred in corn mills and granaries in various industrial centres in England. Champion (Ent. Mo. Mag., 1918, p. 40) records it as having been found under timber and among wood-shavings in London, in company with Ptinus tectus and Niptus hololeucus: and Potter (op. cit. 1919, p. 88) records it from old cotton mills near Manchester, where it was attracted to baits of sugar It is not mentioned in Reitter's "Fauna Germanica: Die Kafer" nor in the addenda at the end of the last volume of that work (Vol. V, 1916), so it had evidently not occurred in Germany up till 1916 within the knowledge of the writers of that book. I have not searched the literature further. Ptinus tectus and Niptus hololeucus, the members of the same family mentioned above, are, like Trigonogenius globulum, found in various stored products. Ptinus tectus further resembles it in being almost cosmopolitan in range. It may be recalled that larvae and adults of Niptus hololeucus have recently been found in cocoa powder from a south German chocolate factory (Rev. Appl. Ent., A.ix, 1921, p. 66). 